\title{
OPERATIONAL CHARACTERISTICS OF FOUR METERING SYSTEMS FOR AGRICULTURAL FERTILIZERS AND AMENDMENTS
}

\author{
JESUS H. CAMACHO-TAMAYO ${ }^{1}$, ANGELA M. BARBOSA ${ }^{2}$, NANCY M. PÉREZ ${ }^{3}$, \\ FABIO R. LEIVA ${ }^{4}$, GONZALO A. RODRÍGUEZ ${ }^{5}$
}

\begin{abstract}
The use of fertilizers and solid amendments in agriculture generates special interest for their effect on crop productivity, as well as for their environmental impact. The efficient use of these products demands knowing their physical and mechanical properties, the storing conditions effect and the operational characteristics of the metering systems used in the fertilizing equipment. In this context, the present study was developed with the purpose of evaluating the operational characteristics of different fertilizing metering systems and to determine the adequate metering system-product operational parameters, using powder lime, powder gypsum, granular 10-30-10 (N$\mathrm{P}-\mathrm{K}$ ), and granular urea. Operational differences were established among four types of commercial fertilizer metering systems, including wire auger, star-shaped feed wheel, feed screw and ridged traction wheel. The study found that the unloading rate depends directly on the fertilizer metering system's rotating speed and is affected by particle size, repose angle, bulk density and moisture content of the applied product. The wire auger and star-shaped feed wheel metering systems were adequate for the distribution of powder products and the feed screw for granulated fertilizers. Furthermore, theoretical and experimental characteristic equations were established, defining curves for calibration and handling of the products plus the rotating speed range in which a better distributing behavior was achieved.
\end{abstract}

KEYWORDS: fertilizer metering system, agricultural machinery, granular material.

\section{CARACTERÍSTICAS DE OPERAÇÃO DE QUATRO DOSADORES PARA A DISTRIBUIÇÃO DE FERTILIZẢNTES E CORRETIVOS COMERCIAIS}

RESUMO: A utilização de fertilizantes e corretivos sólidos na agricultura apresenta especial atenção tanto por seu efeito no incremento da produtividade dos cultivos, como por seu possível impacto ambiental. Para o uso eficiente desses produtos, precisam-se conhecer as características físicas e mecânicas, o efeito das condições de armazenamento e os detalhes de operação dos dosadores utilizados nos equipamentos para adubação. $\mathrm{O}$ presente trabalho foi desenvolvido com o fim de avaliar as características de operação de diferentes dosadores e determinar parâmetros adequados do comportamento dosador-produto usando calcário, gesso agrícola, ureia granular e uma mistura10-30-10 (N-P-K) granular. Estabeleceram-se diferenças de operação de quatro dosadores, incluindo espiral flutuante, rotor horizontal, rosca sem fim e rotor acanalado, encontrando-se que a descarga depende diretamente da velocidade de giro dos dosadores, influenciada pelo tamanho da partícula, pelo ângulo de repouso, pela densidade aparente e pela umidade relativa do produto dosado. Os dosadores espiral flutuante e rotor horizontal foram adequados para a distribuição de produtos em pó e a rosca sem fim para a distribuição de produtos granulados. Além disso, estabeleceram-se as equações teóricas e experimentais que definem as curvas para a calibração e a operação dos produtos, assim como as velocidades de giro que apresentam adequada distribuição.

PALAVRAS-CHAVE: dosador, máquinas agrícolas, material granular.

\footnotetext{
${ }^{1}$ Profesor Asistente, Departamento de Ingeniería Civil y Agrícola, Universidad Nacional de Colombia, Bogotá, D.C., jhcamachot@unal.edu.co

${ }^{2}$ Ingeniera Agrícola, Departamento de Ingeniería Civil y Agrícola, Universidad Nacional de Colombia, Bogotá, D.C., angela_barbosa@hotmail.com

${ }^{3}$ Ingeniera Agrícola, Departamento de Ingeniería Civil y Agrícola, niversidad Nacional de Colombia, Bogotá, D.C., marcela_perez_a@yahoo.es

${ }^{4}$ Profesor Asociado, Facultad de Agronomía, Universidad Nacional de Colombia, Bogotá, D.C., frleivab@unal.edu.co

${ }^{5}$ Director Oficina Asesora, C.I. Tibaitatá, Corporación Colombiana de Investigación Agropecuaria, CORPOICA, Mosquera, Cundinamarca, Colombia, grodriguez@ corpoica.org.co

Recebido pelo Conselho Editorial em: 8-11-2007

Aprovado pelo Conselho Editorial em: 27-9-2009
}

Eng. Agríc., Jaboticabal, v.29, n.4, p.605-613, out./dez. 2009 


\section{INTRODUCTION}

Commercial fertilizers are the most common in agricultural production, since they are easy to produce, transport and apply. Depending on their size they are classified as: powder, for particles between 0.01 and $0.1 \mathrm{~mm}$; crystallized with particles between 0.2 and $1 \mathrm{~mm}$ and granulated with particles between 0.5 and $5 \mathrm{~mm}$ (ORTIZ-CAÑAVATE \& HERNANZ, 1989). MASSOUDI (2001) asserts that these materials present solid as well as fluid behavior characteristics. The material flow in the hopper and its advance throughout the machine elements is affected by grain size distribution and moisture content (FAO, 1994).

Further, the unloading rate of the machine is directly related to the material's density. The hopper's capacity and the type of feeding mechanisms are determined by these characteristics. Other factors affecting the distribution of these products are: size and form of the particles, repose angle and density (WALKER et al., 1997; MOHSENIN, 1986), surface roughness (GRIFT et al., 1997), the in between particles friction coefficient and the metering system's contact surfaceparticle friction coefficient (APHALE et al., 2003).

These characteristics are affected by the handling, storing and field conditions, and specially by the moisture content of the product and the air relative humidity, since solid fertilizers are hygroscopic, increasing up to $8 \%$ their own weight by humidity absorption in a 48-hour time (ALLAIRE \& PARENT, 2004a; 2004b).

High moisture content in granulated materials is undesirable because increases the cohesive forces between the particles themselves and between them and the surfaces in contact (MASSOUDI, 2001), it also delays the fertilizer's flow and, in certain conditions, hindering its movement. This is even more critical for small particles, where the specific surface is greater, since the superficial moisture content is inversely proportional to the particle's diameter. Storing these products for a long period in high humidity conditions is inconvenient, can result in compaction of the product, reducing the porosity and increasing flow resistance.

The study of fertilizer distribution models is of great importance to improve these products' efficiency. Four factors must be considered in these studies: (a) versatility to predict the effects due to material property changes, wind influence and adjustments to the equipment used; (b) development of recommendations to calibrate and operate the equipment for different products; (c) development of recommendations supporting the elaboration of granulated materials like solid fertilizers and (d) generation of tools favoring equipment design for the distribution of these products, with the objective of minimizing environmental risks (WALKER et al., 1997).

This paper presents the results of a research aimed at evaluating the operational characteristics of different metering systems, common to fertilizer application equipment, and determining the adequate metering system-product operational parameters.

\section{MATERIAL AND METHODS}

The experimental work was developed in two stages: the first one was the characterization of the products evaluated and the second one included the construction of the test bench and completing trial runs with the metering systems.

The evaluated commercial products were lime, gypsum, 10-30-10 (N-P-K) and urea. The first two are powder products, with particle size smaller than $0.3 \mathrm{~mm}$ and the last two are granulated, with average particle size of $3 \mathrm{~mm}$. To determine the particle size a sieve set was used with sizes in accordance to the norm ISO 5690/1 (1982).

Table 1 shows other characteristics for these products, taking five samples of the product, in each case, and applying the procedure to find moisture content described in ICONTEC (1985) norm 35, and the MOSHENIN (1986) method to determine the repose angle. 
TABLE 1. Physical property values found for the products used.

\begin{tabular}{ccrc}
\hline \multirow{2}{*}{ Product } & $\mathrm{H}$ & $\rho$ & $\alpha$ \\
\cline { 2 - 5 } & $\%$ & $\mathrm{~kg} \mathrm{~m}^{-3}$ & degrees \\
\hline $10-30-10$ & 2.16 & 1,031 & 40.4 \\
Urea & 1.25 & 709 & 41.0 \\
Lime & 0.66 & 1,313 & 50.0 \\
Gypsum & 18.85 & 696 & 55.0 \\
\hline
\end{tabular}

H: moisture content; $\rho$ : bulk density; $\alpha$ : repose angle

The metering systems evaluated were: feed screw 1 (40.6 $\mathrm{mm}$ thread) and 2 (50.8 $\mathrm{mm}$ thread), ridged traction wheel, wire auger and star-shaped feed wheel (Figure 1), which were chosen considering they are found in fertilizing equipment for crop production. Based on the fertilizer's characteristics (repose angle and bulk density) and the metering system, a test bench was designed to carry out the tests.

The lab tests consisted in adjusting the metering systems according to current field operational conditions. The test considered 12 rotating speeds in a range between 16 and $245 \mathrm{rpm}$, to obtain the calibration curves for each metering system and product. The power transmission system consisted of a Siemens electric motor (model 090-4YA 60, operating at 1,700 rpm), with the respective conduction pulleys and a driving axis where the metering systems were mounted. A Siemens XAM423MM138D electronic speed changer was coupled to the motor, which allows the regulation of its rotational speed in a range between 5 and $1,720 \mathrm{rpm}$. The mean mass flow was measured by collecting the product for a period of time (about $60 \mathrm{~s}$ ). The fertilizer was then weighed to the nearest $0.01 \mathrm{~g}$.
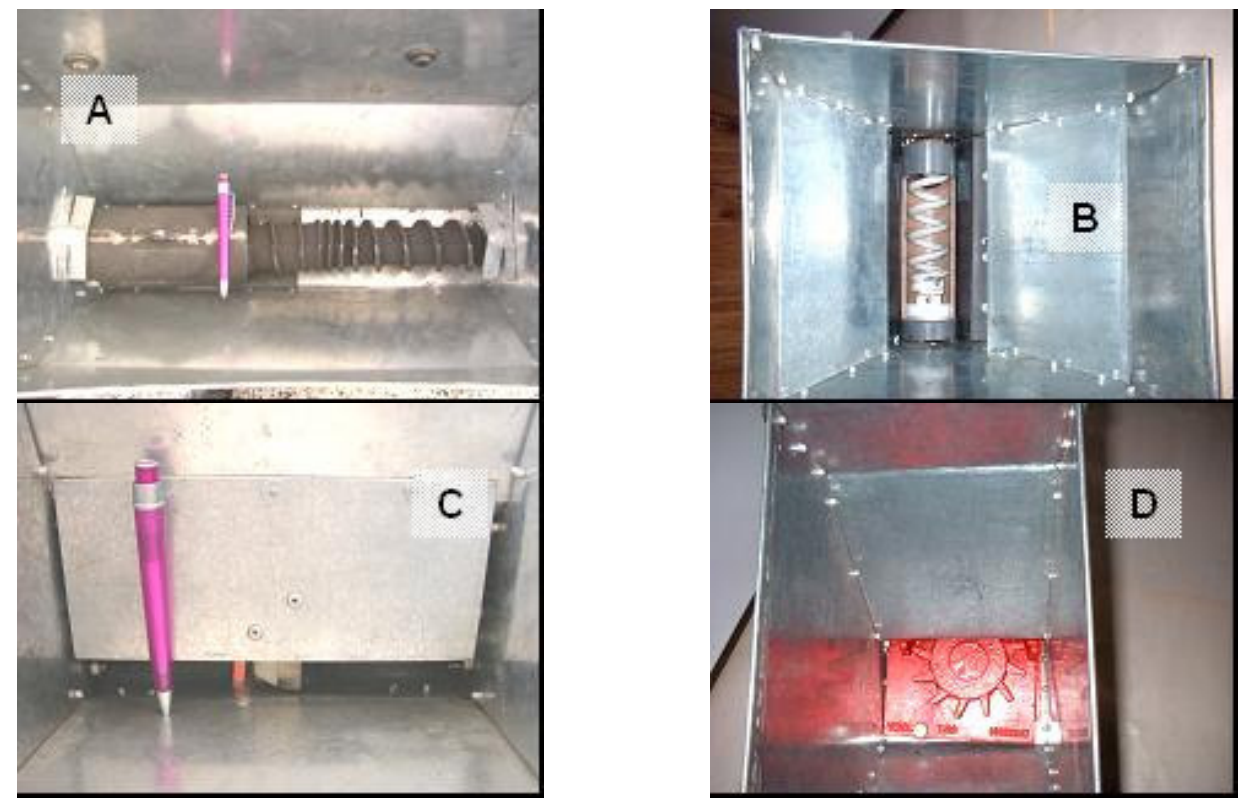

FIGURE 1. Fertilizer metering systems evaluated: A-Feed screw; B-wire auger; C-ridged traction wheels; D-star-shaped feed wheel.

The statistical analysis used was a factorial arrangement allowing the simultaneous analysis of the evaluated parameters. For that, the five fertilizer metering systems were analyzed, with four products, in 12 rotating speeds and four replications, for a total of 960 tests. For each parameter a variance analysis was carried out with Duncan 5\% significance tests, to establish differences among fertilizer metering system, products and axis speed averages. Likewise, the coefficient of variation (C.V.) was calculated to establish the fertilizer application uniformity, for each type of metering systems and product. Finally, the characteristic unloading rate equations, for each metering system, 
were obtained from product unloading, axis rotational speed, bulk density, repose angle, moisture content and average particle size. Analysis of graphs and statistics from pilot studies (SVENSSON, 1994) indicated that only linear effects of the measured variables could be expected to influence unloading rate from the fertilizer metering systems. The statistical analysis of the experiments was done using SPSS v.12 (SPSS Inc., 2003).

\section{RESULTS AND DISCUSSION}

The variance analysis for the behavior of the variable unloading rate $\left(\mathrm{g} \mathrm{min}^{-1}\right)$ and for the unitary unloading rate $\left(\mathrm{g} \mathrm{rev}^{-1}\right)$, related to: type of product, fertilizer metering system and rotation speed, measured at the axis, showed that all these parameters and their possible combinations have a certain degree of significance on the analyzed variables. The linear regression model was the most adequate for the dependent variables with a determination coefficient $\left(\mathrm{R}^{2}\right)$ of 0.97 for unloading rate and 0.99 for unitary unloading rate as shown by the sum of squares.

\section{Behavior of product-metering system}

The comparison between products showed differences for unloading rate $\left(\mathrm{g} \mathrm{min}^{-1}\right)$ (Table 2) and for unitary unloading rate $\left(\mathrm{g} \mathrm{rev}^{-1}\right)$ (Table 3$)$. The lowest unloading rate happened for gypsum, corresponding to its low density, high repose angle and considerable moisture content. The highest unloading rate occurred with lime, which has greater bulk density and smaller particle size. The granulated products urea and 10-30-10 showed intermediate unloading rate values. This behavior was compatible with the results found by REUMERS et al. (2003) and described by ALLAIRE \& PARENT (2004a, 2004b) for granular and powder materials.

TABLE 2. Comparison per product of average unloading rate $\left(\mathrm{g} \mathrm{min}^{-1}\right)$ per metering system.

\begin{tabular}{cccccccccccc}
\hline Metering system & \multicolumn{2}{c}{ Gypsum } & \multicolumn{2}{c}{ Urea } & \multicolumn{3}{c}{$10-30-10$} & \multicolumn{2}{c}{ Lime } & \multicolumn{3}{c}{ Average } \\
\hline Feed screw 2 & 980 & aA & 2,058 & abB & 3,328 & abC & 3,772 & abC & 2,535 & B \\
Feed screw 1 & 1,608 & bcA & 2,191 & bB & 3,142 & abC & 3,379 & aC & 2,580 & C \\
Ridged traction wheel & 1,300 & abA & 1,719 & aA & 2,592 & aB & 3,599 & abC & 2,303 & A \\
Wire auger & 1,914 & cA & 2,447 & bA & 3,859 & bB & 4,533 & bcB & 3,188 & D \\
Star-shaped feed wheel & 1,687 & cA & 2,525 & bB & 3,651 & bC & 5,017 & cD & 3,220 & D \\
\hline Average & 1,498 & A & 2,188 & B & 3,314 & C & 4,060 & D & & \\
\hline
\end{tabular}

Values followed by different lower case letter in each column or capital letter in each row indicate differences, according to Duncan Test $(P<0.05)$.

Table 2 shows the unloading rate behavior per metering system. The wire auger and the starshaped feed wheel showed the highest unloading rate with not significant differences between them. The ridged traction wheel presented the lowest unloading rate since it has the smallest unloading area respect to the other metering systems. The unitary unloading rate for both threads with the feed screw was in the same group, without differences between them but there were differences for the unloading rate. The wire auger and star-shaped feed wheel are adequate to apply high unloading rate products $\left(\mathrm{kg} \mathrm{ha}^{-1}\right)$, as it is generally the case for agricultural amendments; in contrast, for low unloading rate the best choice is the ridged traction wheel.

The coefficient of variation (C.V.) analysis per product showed high lime unloading rate uniformity for all speeds and metering systems evaluated (Table 3). On the other hand, gypsum presented the highest unloading rate irregularity; consequently, handling difficulties, probably because of its low density $\left(696 \mathrm{~kg} \mathrm{~m}^{-3}\right)$, high repose angle $\left(55^{\circ}\right)$ and high moisture content $(18 \%)$.

To evaluate under different conditions the versatility of each system, the unloading C.V. per metering system was analyzed taking into account its general behavior with all speeds and products evaluated (Table 3). The analysis showed that feed screw 1 presented the highest uniformity, principally for granular products (GUNDOGDU, 2004), followed by the wire auger. Feed screw 2 had the greatest variation. 
TABLE 3. Mean value comparison between unitary unloading rates $\left(\mathrm{g} \mathrm{rev}^{-1}\right)$ per metering system.

\begin{tabular}{cllccc}
\hline Metering system & Gypsum & Urea & $10-30-10$ & Lime & Average \\
\hline Feed screw 2 & $7.98 \mathrm{aA}$ & $15.74 \mathrm{bB}$ & $26.54 \mathrm{cC}$ & $29.18 \mathrm{bD}$ & $19.86 \mathrm{~b}$ \\
C.V. $(\%)$ & 19.78 & 6.75 & 8.04 & 8.14 & 43.86 \\
Feed screw 1 & $11.94 \mathrm{cA}$ & $17.22 \mathrm{cB}$ & $23.79 \mathrm{bC}$ & $26.16 \mathrm{aD}$ & $19.78 \mathrm{~b}$ \\
C.V. $(\%)$ & 11.06 & 10.19 & 5.46 & 11.30 & 29.96 \\
Ridged traction wheel & $10.79 \mathrm{bA}$ & $13.31 \mathrm{aB}$ & $19.71 \mathrm{aC}$ & $27.13 \mathrm{aD}$ & $17.74 \mathrm{a}$ \\
C.V. (\%) & 32.94 & 14.13 & 9.62 & 14.71 & 39.73 \\
Wire auger & $15.58 \mathrm{eA}$ & $19.00 \mathrm{~dB}$ & $29.96 \mathrm{dC}$ & $34.19 \mathrm{cD}$ & $24.68 \mathrm{c}$ \\
C.V. (\%) & 15.83 & 9.45 & 3.84 & 6.93 & 32.14 \\
Star-shaped feed wheel & $13.50 \mathrm{aA}$ & $21.30 \mathrm{eB}$ & $30.97 \mathrm{dC}$ & $38.66 \mathrm{dD}$ & $26.11 \mathrm{~d}$ \\
C.V. (\%) & 9.91 & 27.66 & 25.53 & 9.18 & 41.72 \\
Media & $11.96 \mathrm{~A}$ & $17.31 \mathrm{~B}$ & $26.19 \mathrm{C}$ & $31.06 \mathrm{D}$ & \\
C.V. $(\%)$ & 28.28 & 23.13 & 21.42 & 19.09 & \\
\hline
\end{tabular}

Values followed by different lower case letter in each column or capital letter in each row indicate differences, according to Duncan Test $(P<0.05)$.

The wire auger type metering system turned up particularly adequate to apply lime, 10-30-10 and urea, with C.V. values relatively low (Table 3). In turn, the star-shaped feed wheel type metering system presented a good behavior in the unloading rate of gypsum, with a variation coefficient of $9.91 \%$. In contrast, the ridged traction wheel showed disadvantages with respect to the other metering systems, which translated into low uniformity distribution, especially for powder products such as lime and gypsum. The star-shaped feed wheel type metering system proved inadequate for granulated products (urea and 10-30-10), with high unitary unloading rate C.V. values. These outputs must be considered with caution since vibration effect that may occur at field conditions has not been taken into account.

\section{Behavior of the axis speed}

The unloading rate showed to be directly proportional to the metering system's axis speed for all meters tested (Table 4), with differences among the speeds evaluated. For the unitary unloading rated, at the beginning of the test it was progressively reduced as the axis speed increased (with differences), reaching a constant value from $81.1 \mathrm{rpm}$ on. This is probably caused by the particles having more time to settle in the metering system at low speeds, described like "fullness effect" by YU \& ARNOLD (1996). This result is important for field calibration tests of fertilizing equipment, since this calibration is usually carried out at low rotational metering system speeds, which are not the actual operational values, thus introducing considerable errors.

TABLE 4. Average values for unloading rate and unitary unloading rate versus axis rotation speed.

\begin{tabular}{cccc}
\hline Axis Speed $(\mathrm{rpm})$ & $\mathrm{N}$ & Unloading $\left(\mathrm{g} \mathrm{min}^{-1}\right)$ & Unitary $^{-1}$ Unloading $\left(\mathrm{g} \mathrm{rev}^{-1}\right)$ \\
\hline 18.6 & 80 & 465.9 & $24.93 \mathrm{a}$ \\
38.1 & 80 & 904.4 & $23.58 \mathrm{~b}$ \\
57.8 & 80 & $1,289.8$ & $22.37 \mathrm{c}$ \\
81.1 & 80 & $1,716.2$ & $21.17 \mathrm{~d}$ \\
101.7 & 80 & $2,121.0$ & $20.81 \mathrm{~d}$ \\
121.0 & 80 & $2,517.8$ & $20.84 \mathrm{~d}$ \\
142.8 & 80 & $2,917.8$ & $20.48 \mathrm{~d}$ \\
163.0 & 80 & $3,355.4$ & $20.65 \mathrm{~d}$ \\
181.5 & 80 & $3,849.9$ & $21.23 \mathrm{~d}$ \\
202.9 & 80 & $4,327.6$ & $21.39 \mathrm{~d}$ \\
222.4 & 80 & $4,641.4$ & $20.92 \mathrm{~d}$ \\
243.7 & 80 & $5,038.3$ & $20.73 \mathrm{~d}$
\end{tabular}

Values followed by different lower case letter in each column indicate differences, according to Duncan Test $(P<0.05)$. $\mathrm{N}$ : Number of samples. 


\section{Characteristic experimental curves for the metering systems}

The unloading rate behavior at different axis operation speeds was linear for the metering systems with a relation of the form $\mathrm{Y}=\mathrm{AX}$ (Table 5). The high $\mathrm{R}^{2}$ values confirm such a lineal behavior. However, the ridged traction wheel exhibited a non-linear behavior at axis speeds over $160 \mathrm{rpm}$ (Figure 2). GUNDOGDU (2004) and SVENSSON (1994) also reported high correlations between unloading rate and axis speed. The lowest unloading rates for 10-30-10 and urea were found with ridged traction wheel meanwhile for gypsum the feed screw 2 showed the lowest unloading rates. In the case of lime, feed screw 1 reported the lowest unloading rates at axis speeds over $160 \mathrm{rpm}$. On the other hand, there was greater uniformity in the parameters evaluated for the granulated products than for the powder ones. Urea and gypsum presented the lowest unloading rate for all metering systems evaluated. It is important to note that the greatest dispersion in unloading rates among the assessed metering systems was found with gypsum.

TABLE 5. Coefficient values (A) for the unloading rate equation $(Y)$ for each product in function of axis speed $(\mathrm{X})$ per metering system.

\begin{tabular}{ccrrrr}
\hline Product & & Lime & $10-30-10$ & Urea & Gypsum \\
\hline \multirow{2}{*}{ Feed screw 2 } & $\mathrm{A}$ & 29.39 & 25.08 & 17.55 & 7.32 \\
& Standard error & 0.32 & 0.12 & 0.09 & 0.19 \\
& $\mathrm{R}^{2}$ & 0.992 & 0.998 & 0.961 & 0.982 \\
\hline \multirow{2}{*}{ Feed screw 1 } & $\mathrm{A}$ & 25.40 & 23.94 & 16.32 & 12.38 \\
& Standard error & 0.21 & 0.15 & 0.15 & 0.11 \\
& $\mathrm{R}^{2}$ & 0.994 & 0.996 & 0.991 & 0.995 \\
\hline \multirow{3}{*}{ Ridged traction wheel } & $\mathrm{A}$ & 27.65 & 20.05 & 12.80 & 9.81 \\
& Standard error & 0.53 & 0.20 & 0.32 & 0.18 \\
& $\mathrm{R}^{2}$ & 0.93 & 0.988 & 0.908 & 0.973 \\
\hline \multirow{2}{*}{ Wire auger } & $\mathrm{A}$ & 34.89 & 29.33 & 18.24 & 14.17 \\
& Standard error & 0.32 & 0.17 & 0.15 & 0.22 \\
& $\mathrm{R}^{2}$ & 0.994 & 0.998 & 0.996 & 0.973 \\
\hline \multirow{2}{*}{ Star-shaped feed wheel } & $\mathrm{A}$ & 37.98 & 27.18 & 18.40 & 12.56 \\
& Standard error & 0.29 & 0.26 & 0.26 & 0.14 \\
& $\mathrm{R}^{2}$ & 0.995 & 0.999 & 0.968 & 0.984 \\
\hline
\end{tabular}



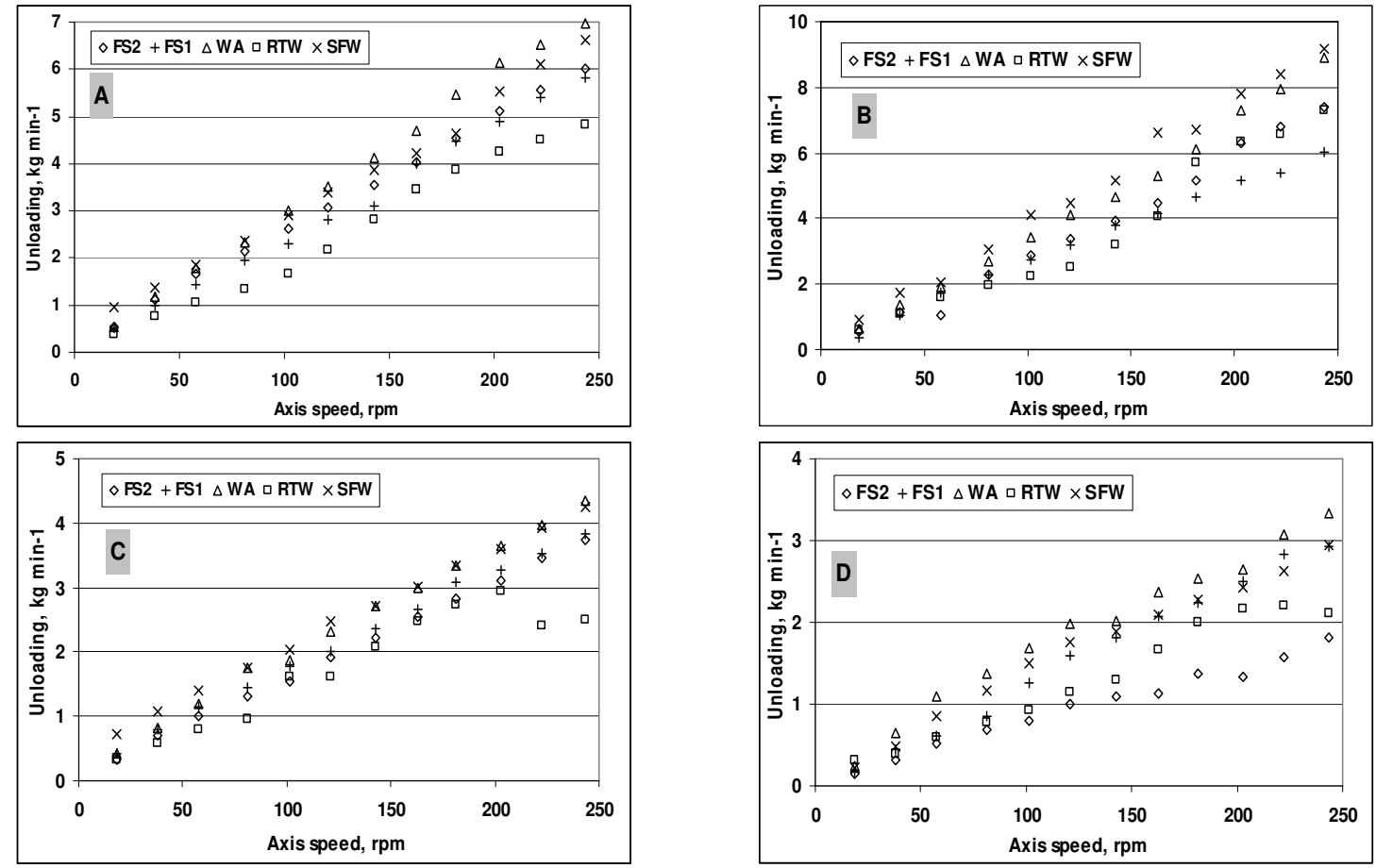

FIGURE 2. Characteristic experimental curves. A-10-30-10; B-Lime; C-Urea; D-Gypsum. FS2: feed screw 2; FS1: feed screw 1; WA: wire auger; RTW: ridged traction wheels; SFW: star-shaped feed wheel.

\section{Characteristic equations for the metering systems}

The unloading rate characteristic equations for each metering system were found through linear regression models, taking into account each product's physical properties and the operational speeds evaluated (ALLAIRE \& PARENT, 2004a; GUNDOGDU, 2004; REUMERS et al., 2003; YU \& ARNOLD, 1996; SVENSSON, 1994; DE, 1989). The regression models found are of the form:

$$
\mathrm{y}=\mathrm{A} \mathrm{v}_{\mathrm{e}}+\mathrm{B} \rho+\mathrm{C} \mathrm{a}_{\mathrm{r}}+\mathrm{DH}+\mathrm{E} \varphi_{\mathrm{m}}
$$

where,

$\mathrm{y}$ - the unloading rate of the product, $\mathrm{g} \mathrm{min}^{-1}$;

$\mathrm{v}_{\mathrm{e}}$ - the axis speed, rpm;

$\rho$ - bulk density, $\mathrm{kg} \mathrm{m}^{-3}$;

$\mathrm{a}_{\mathrm{r}}$ - repose angle (degrees);

$\mathrm{H}$ - moisture content (\%);

$\varphi_{\mathrm{m}}$ - average product particle size $(\mathrm{mm})$, and

$\mathrm{A}, \mathrm{B}, \mathrm{C}, \mathrm{D}$ and $\mathrm{E}$-non-dimensional factors depending on the product's characteristics (Table 9).

The E coefficient for the feed screw 1 or 2 was zero because the correlation between unloading rate and the particle average diameter was not significant. SVENSSON (1994) found this behavior for NPK (20-3-5) unloading rate for a roller feeder. Consequently, this variable was excluded from the model and assumed non-unloading rate representative for this metering system, reaching a correlation coefficient of 0.953 . Thus, this metering system's unloading rate turned up directly dependent on product density, moisture content and axis speed, but inversely dependent on the repose angle (Table 6). 
TABLE 6. Coefficient values of the unloading rate equations for each metering system.

\begin{tabular}{lcccrc}
\hline Metering system & $\mathrm{A}$ & $\mathrm{B}$ & $\mathrm{C}$ & $\mathrm{D}$ & $\mathrm{E}$ \\
\hline Feed screw 2 & 18.76 & 4.20 & $-4,830$ & 17.74 & 0 \\
Feed screw 1 & 18.80 & 2.92 & $-3,380$ & 2.92 & 0 \\
Ridged traction wheel & 18.19 & 2.82 & $-2,891$ & -10.16 & -205.85 \\
Wire auger & 23.78 & 4.41 & $-5,017$ & 35.31 & -102.50 \\
Star-shaped feed wheel & 22.01 & 3.81 & $-3,248$ & -33.98 & -258.46 \\
\hline
\end{tabular}

No variable was excluded in the mathematical model for the ridged traction wheel and starshaped feed wheel. The unloading rate depends directly on the axis speed and to a lesser degree on the product's bulk density and inversely on the repose angle, the moisture content and particle size (DE, 1989). In turn, the wire auger unloading rate depended directly on moisture content, axis speed and bulk density. The repose angle and average particle diameter, related to each other, affected inversely this system's unloading rate.

\section{CONCLUSIONS}

The unloading rate $\left(\mathrm{g} \mathrm{min}^{-1}\right)$ of the analyzed fertilizers presents a linear relation with the metering system's axis rotation speed, virtually for all the systems evaluated, which is in accordance with previous works. Likewise, the unloading rate is directly affected by the bulk density but inversely by the product's repose angle.

The unitary unloading rate $\left(\mathrm{g} \mathrm{rev}^{-1}\right)$ is affected by the size of the particle, axis speed and product's bulk density.

Considering the type of fertilizer to be applied, this study has shown adequate operational speed range for different metering systems. The characteristic equations found may be used as preliminary calibration curves for the metering systems and fertilizer studied.

The wire auger metering system was the best for distributing solid products, while the ridged traction wheels metering system presented low unloading rate uniformity.

The star-shaped feed wheel and the wire auger were adequate for distributing great amounts of fertilizers and amendments, while the ridged traction wheel did it for small amounts of such products.

The feed screw 1 and 2 are suitable metering systems for granulated products but not for powder products. The unloading rate uniformity was inversely affected by the granularity of the products.

\section{ACKNOWLEDGEMENTS}

To Instituto Colombiano para el Desarrollo de la Ciencia y la Tecnología "Francisco José de Caldas" (COLCIENCIAS), for financial support.

\section{REFERENCES}

ALLAIRE, S.E.; PARENT, L.E. Physical properties of granular organic-based fertilizers. Part 1: static properties. Biosystems Engineering, United Kingdom, v.87, p.79-87, 2004a.

ALLAIRE, S.E.; PARENT, L.E. Physical properties of granular organic-basec fertilizers. Part 2: Dynamic properties related to water. Biosystems Engineering, United Kingdom, v.87, p.225-236, 2004b.

APHALE, A.; BOLANDER, N.; PARK, J.; SHAW, L.; SVEC, J.; WASSGREN, C. Granular fertilizer particle dynamics on and off a spinner spreader. Biosystems Engineering, United Kingdom, v.85, p.319-329, 2003. 
DE, D. Flow behaviour of chemical fertilizers as affected by their properties. Journal of Agricultural Engineering Research, United Kingdom, v.42, p.235-249, 1989.

FAO. Principios y prácticas de prueba y evaluación de máquinas y equipos agrícolas. Rome, 1994. 281 p. Boletín de Servicios Agrícolas de la FAO.

GRIFT, T.E.; WALKER J.T.; HOFSTEE, J.W. Aerodynamic properties of individual fertilizer particles. Transaction of the ASAE, St. Joseph, v.40, n.1, p.13-20, 1997.

GUNDOGDU, M.Y. Design improvements on rotary valve particles feeders used for obtaining suspended airflows. Powder Technology, Lausanne, v.139, n.1, p.76-80, 2004.

ICONTEC. Norma 35: Determinación de humedad en fertilizantes granulados. Bogotá: Instituto Colombiano de Normas Técnicas y Certificación, 1985.

ISO. Equipment for distributing fertilizers: Test methods - Part 1: Full width fertilizer distributors. Geneve, 1982.

MASSOUDI, M. On the flow of granular materials with variable material properties. International Journal of Non-Linear Mechanics, Oxford, v.36, n.1, p.25-37, 2001.

MOHSENIN, N.N. Physical properties of plant and animal materials: structure, physical characteristics, and mechanical properties. New York: Gordon and Breach, 1986. 892 p.

ORTIZ-CAÑAVATE, J.; HERNANZ, J.L. Técnica de la mecanización agraria. $3^{\text {rd }}$ ed. Madrid: Ediciones Mundi-Prensa, 1989. 642 p.

REUMERS, J.; TIJSKENS, E.; RAMON, H. Experimental characterization of the tangential and cylindrical fertiliser distribution pattern from a spinning disc: a parameter study. Biosystems Engineering, United Kingdom, v.86, n.3, p.327-337, 2003.

SPSS. SPSS Statistical Software. Version 12.0. Illinois, 2003.

SVENSSON, J.E.T. Effects of constructional and operational variables on the mean mass flow of particulate fertilizer using a studded roller feeder. Journal of Agricultural Engineering Research, United Kingdom, v.59, n.4, p.221-230, 1994.

WALKER, J.T.; GRIFT, T.E.; HOFSTEE, J.W. Determining effects of fertilizer particle shape on aerodynamic properties. Transaction of the ASAE, St. Joseph, v.40, n.1, p.21-27, 1997.

YU, Y.; ARNOLD, P.C. The influence of screw feeders on bin flow patterns. Powder Technology, Lausanne, v.88, n.1, p.81-87, 1996. 